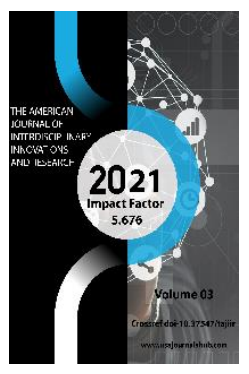

\title{
Innovative Education Is An Important Factor To Increase The Efficiency Of Economic Education
}

\author{
Shavkat Sobirovich Oltaev \\ Senior Lecturer, Candidate Of Economic Sciences, Samarkand Institute Of Economics And \\ Service, Tashkent, Uzbekistan
}

\begin{abstract}
Journal Website: https://theamericanjou rnals.com/index.php/ta jiir

Copyright: Original content from this work may be used under the terms of the creative commons attributes 4.0 licence.
\end{abstract}

\section{ABSTRACT}

This article discusses the importance of innovative education for educational institutions today and the role of innovation. At the same time, it is shown that today they are able to increase the effectiveness of education through the use of innovative education. It is stated that meeting the requirements of today through the use of new innovative technologies in educational institutions imposes a great responsibility on teachers and educators of educational institutions.

\section{KEYWORDS}

Innovation, Global, Local, Modular System, Interactive, Case-Study, Pedagogical Technology.

\section{INTRODUCTION}

As Uzbekistan is on the path of radical renewal and innovative development in all spheres, including political, economic and social, it is expedient, first of all, to radically reform the education system, identify consistent measures to improve the quality of education and ensure the implementation of roadmaps. In his address to the Oliy Majlis, the President of the Republic of Uzbekistan emphasized that "our only goal is to make Uzbekistan competitive in the world in the field of science, intellectual potential, modern personnel, high technology" [1]. Nowadays, in the period of changes in the educational process, economic education is of great importance and is a continuous process that requires its own peculiarities. In such a process it is necessary to know the methods of pedagogical and 
psychological influence on the effectiveness of economic education. One of the pedagogical and psychological factors in the formation of economic education in the individual is the use of various forms of pedagogical technologies, various economic conversations with students, discussions, debates, encouraging them to think actively through the creation of problematic situations. Economic education is an education that is constantly evolving and improving compared to other areas. Therefore, in the process of providing economic education, a great deal of responsibility and courage is required from the teaching staff.

It is emphasized that all teachers and educators in educational institutions should diligently and persistently study the experience of not only Uzbekistan, but also foreign countries, and then teach their students. Because the effectiveness of economic education depends on the personality of the teacher. To do this, it is necessary to skillfully use various pedagogical technologies in the classroom. Educators must have a good knowledge of economic laws and regulations, reflect their worldview, as well as their ability to speak, their knowledge must lead to the formation of a serious attitude of students to the learning process. It is obvious that in the process of teaching in educational institutions, all educators are achieving the effectiveness of economic education through the use of a number of new innovative innovations through economic education. A number of scientific researches have also been carried out. Our economists and educators improve their skills in foreign countries, create smart classrooms, SMART rooms in educational institutions based on foreign experience and help students to form and deepen their economic knowledge. Studies by Yunfu Hu and Aiya Li [7] have shown that the development of human karma affects the country's innovation. The study found that in a country where there is a shortage of qualified personnel, the level of economic development is not high.

Merve Dogruel Anulu, Seniye Umit A study by Euphrates [8] states that countries can assess their economy and business development through international innovation indices.

\section{RESEARCH METHODOLOGY}

In the current context of globalization, the innovation process is rapidly entering. As we all know, today is very rich in innovative changes and developments. Innovations are up-to-date, important, new approaches formed in a system. They are born on the basis of initiative and innovation and are promising for the development of educational content. It also has a positive impact on the development of the education system as a whole. Innovation is the end result of a technology, form, or method in a particular field of activity or production, a new approach to solving a problem, or the application of a new technological process that is known to lead to greater success than ever before. Innovations in the education system today can be classified as follows: first, depending on the direction of activity (in the pedagogical process, management); second, according to the description of the changes made (local, modular, systemic); third, according to the source of origin. 
It is possible to apply innovations in every process. In order for students studying economics to have a high level of economic knowledge, it will be necessary to teach them through case studies, problem-solving lessons, and brainstorming methods so that they can study and learn about various economic processes. Through the application of innovations in the educational process, the development of knowledge and skills in the formation of students' economic knowledge is achieved. Innovative technologies are aimed at achieving a predetermined goal based on ensuring a high level of student activity in the classroom. Because in this process the teacher and the student become active. All pedagogical technologies used in the educational process help to form in the student learning process such feelings as selfconfidence, independent thinking, interaction, independent acquisition of knowledge.

\section{ANALYSIS AND RESULTS}

When classes are organized on the basis of innovative technologies, the need and aspiration of students to innovate will be stronger. It will also make the quality of education more effective. In the process of economic education, the influence of innovative teaching methods on the manifestation of cognitive processes is important. In order to increase the effectiveness of economic education, it is advisable to organize the learning process using Internet messages and in the form of various slides. Because such a process not only forms in students the ability to think creatively, to be active, to communicate freely, to control their behavior, but also to master the culture and level of communication. After all, the manifestations of human spirituality, the spiritual world, are manifested through his communication. The newer the information system in education and the more it is transmitted in an illuminated way based on innovative technologies, the higher the level of quality in the learning process.

Economic education is a continuous process that requires specific aspects. At all stages of human life, economic concepts, laws, categories, laws are manifested in the form of specific ideas, knowledge, skills, abilities. It is necessary to know the methods of pedagogical and psychological influence on the effectiveness of economic education. One of the pedagogical and psychological factors in the formation of economic education in the individual is the use of various forms of pedagogical technologies, conversations with students on various economic topics, discussions, debates, encouraging them to think actively through problem situations. The influence of educators is also strong for the pedagogical-psychological factors of the formation of economic education in students to be effective.

When considering the effectiveness of the use of innovative technologies in the system of economic education, it is necessary to consider the interaction of teacher and student, which can regulate and target the learning process. Innovative technologies are aimed at achieving a predetermined goal based on ensuring a high level of student activity in the classroom. Also, any innovation in the educational process cannot be an innovation. Innovation is carried out within the existing theory, limited in scope and time, methods are updated, and the result is an improvement on the previous system. 
Innovation will be systematic and sustainable, will design a new system of activities in a particular practice, will completely update the subjects of practice. At the same time, the directions of activity are opened, modern technologies are created, new qualitative results of activity are achieved, as a result, the practice itself is renewed.

Innovative changes in the educational process, the introduction of any innovations into the system can be done directly by updating and modifying the activities of the teacher. Innovative education is a continuous work on the basis of innovations, which is formed and improved over a long period of time. Innovative activity is aimed at solving a number of problems that arise as a result of incompatibility of traditional norms with new social requirements or the collision of a newly formed norm of practice with the emerging norm. Innovations contribute to the development of education by constantly bringing innovations to pedagogical activity, have a positive impact on pedagogical activity.

\section{CONCLUSIONS}

It should be noted that today, innovative technologies are a pedagogical process, as well as innovations and changes in the activities of teachers and students, the implementation of which is based on the full use of interactive methods. Interactive methods are collective thinking, that is, they are methods of pedagogical influence and are an integral part of the content of education. The peculiarity of these methods is that they are carried out only through the joint work of teachers and students. Today in our country there are enough opportunities to combine the scientific potential of specialists. Ensuring the unity of theory and practice opens the way to defining the essence of pedagogical technology. Pedagogical technology reflects the activity within the framework of combining theoretical and practical research in this field. Therefore, in order to increase the efficiency of the economic education process, the formation of strong theoretical knowledge, activities, skills and abilities of students, to ensure their transformation into professional skills, the use of new pedagogical technologies in the teaching process is a matter of urgency and social necessity. The introduction of new pedagogical technologies in the process of economic education provides a qualitative change in the content of the overall process aimed at training.

\section{REFERENCES}

1. Address of the President of the Republic of Uzbekistan Shavkat Mirziyoyev to the Oliy Majlis of December 22, 2017. People's Word newspaper, December 23, 2017.

2. Yuldashev J.E., Usmonov S. Advanced pedagogical technologies. - $\mathrm{T}$.: Teacher, 2004.

3. Pedagogy: 1000 answers to 1000 questions / Met. hand U.I.Inoyatov, N.A.Muslimov, M.Usmonboeva, D.Inogomova. - T .: TSPU named after Nizami, 2012. - 193 p.

4. Tolipov U., Usmonboeva M. Applied bases of pedagogical technologies - $\mathrm{T}$ :2006. II

5. Avliyakulov N.X., Musaeva N.N. Modular learning technologies. - $\mathrm{T}$.: "Science and Technology" Publishing House, 2007. - 97 p. 
6. Ishmukhamedov R., Abdukodirov A., Pardaev A. Innovative technologies in education $\quad$ I Practical recommendations. - T .: "Talent" fund, 2008.-180 p.

7. Ruzieva D., Usmonbaeva M., Kholikova: Interactive methods: essence and application / Method. hand - T .: Nizami DTPU, 2013. - $115 \mathrm{p}$.

8. Yunfu Xu, Aiya Li, (2020). The relationship between innovative human capital and interprovincial economic growth based on panel data model and spatial econometrics, Journal of Computational and Applied Mathematics, Volume 365, 2020, 112381, ISSN 0377-0427, https://doi.org/10.1016/j.cam.2019.1123 81

9. http://www.sciencedirect.com/scienc e/article/pii/S037704271930384X

10. Merve Dogruel Anu§lu, Seniye Umit Firat (2019). Clustering analysis application on Industry 4.0-driven global indexes, Procedia Computer Science, Volume 158, 2019, Pages 145152, 1877า0509, https://doi.org/10.1016/j.procs.2019.09. 037 